\title{
Nurty myślenia o dydaktyce
}

Analizowanie rozwoju dydaktyki ogólnej - jednej z podstawowych subdyscyplin pedagogiki - śledzenie jej przemian, ewaluowania przedmiotu badań, zadań, funkcji, wnikanie w jej związki z innymi naukami, inspiracje poznawcze i badawcze, impulsy i kierunki wzrastania, eksplorowanie wielości koncepcji dydaktycznych, paradygmatów i odmian dydaktyki - to zadanie niezwykle intrygujące poznawczo i aplikacyjnie. Celem artykułu jest przedstawienie trzech nurtów myślenia o dydaktyce: 1) jako nauce, 2) sztuce i 3) przedmiocie akademickim. Prezentowana narracja stanowi swoistą autodiagnozę dydaktycznego myślenia i działania.

\section{Dydaktyka jako nauka}

O dydaktyce ogólnej należy myśleć jako o podstawowej subdyscyplinie pedagogiki, która obok pedagogiki ogólnej, teorii wychowania, historii wychowania i myśli pedagogicznej, należy do czterech kanonicznych nauk pedagogicznych. Uwzględniając nową systematykę dziedzin naukowych ${ }^{1}$, która od października 2018 roku przybrała dwustopniowy podział nauk, obejmując: 7 dziedzin nauki i 1 dziedzinę

1 Na mocy rozporządzenia Ministra Nauki i Szkolnictwa Wyższego z dnia 20 września 2018 r. 
sztuki, interesująca nas dydaktyka ogólna, jako dyscyplina pedagogiczna sytuuje się w dziedzinie nauk społecznych (obok psychologii, ekonomii i finansów, geografii społeczno-ekonomicznej i gospodarki przestrzennej, prawa kanonicznego, nauk socjologicznych, nauk prawnych, nauk o bezpieczeństwie, nauk o komunikacji społecznej i mediach, nauk o polityce i administracji, nauk o zarządzaniu i jakości). Podobnie w klasyfikacji OECD ${ }^{2}$ obejmującej 6 dziedzin nauki i 1 dziedzinę sztuki, widnieje w naukach społecznych.

Warto przypomnieć, że do 2011 roku pedagogika, a więc i dydaktyka była przypisana do dziedziny nauk humanistycznych, podobnie jak psychologia, nauki o polityce, socjologia. Rozporządzeniem ministerialnym z 2011 roku przeniesiona została do nauk społecznych, co utrzymano do dzisiaj. Podział i przeciwstawienie humanistyki naukom społecznym jest sprzeczny z rzeczywistością, którą one badają i poddają ustawicznej zmianie. Zabieg ten nie uwzględnia specyfiki przedmiotów badań subdyscyplin pedagogicznych. Jedne z nich bardziej przynależą do humanistyki (np. dydaktyka ogólna), gdy inne figurują w zbiorze nauk społecznych (np. pedagogika społeczna, pedagogika pracy, animacji kultury).

I tu pojawia się pierwszy dylemat podnoszony w dyskusjach o statusie interesującej nas nauki: na ile dydaktyka/pedagogika jest nauką społeczną, a na ile humanistyczną?

Dylemat ów wiąże się ze sposobem kreowania dydaktyki ogólnej jako dyscypliny naukowej związanej z przyjętymi orientacjami metodologicznymi wynikającymi z wiodących założeń poznawczych. Dydaktykę ogólną uprawia się w jakiejś części na wzór nauk społecznych, przyrodniczych, celem poznania czyniąc „opis” i „wyjaśnianie” faktów, zjawisk i procesów związanych z kształceniem, np. próbuje się mierzyć wiadomości i umiejętności uczniów za pomocą testów osiągnięć szkolnych. Stosując tę orientację „technologiczną”, „prakseologiczną” bliżej nam do nauk społecznych operujących głównie metodami ilościowymi.

Jednakże błędem i nieporozumieniem byłoby redukowanie dydaktyki do nauki społecznej w paradygmacie scjentystycznym, nauki instrumentalnej, pozbawionej odniesień do wartości, do antropologii

2 Organizacja Współpracy Gospodarczej i Rozwoju w 2004 roku przyjęła sygnalizowaną w tekście systematykę nauk. 
filozoficznej, do humanistycznych analiz językowych, a więc rezygnującej z metafizyki, uniwersaliów, kulturowych sensów. Oznaczałoby to wykluczenie $\mathrm{z}$ przedmiotu badań dydaktycznych (w teorii i praktyce), tego, co niemierzalne, niedające się empirycznie, jednoznacznie udowodnić.

Trudno odmówić racji Bogusławowi Śliwerskiemu, który pisze: „Lokując pedagogikę w naukach społecznych, wyrządzono badaczom szczególną krzywdę. Sprowadzono ją bowiem do wyjałowionej aksjonormatywnie nauki, która ma służyć głównie interesariuszom, zamawiającym dowody na skuteczność kształcenia, wychowania, opieki czy terapii"

Dydaktykę ogólną uprawia się też na wzór nauk humanistycznych. Wówczas celem poznania dydaktycznego jest „rozumienie”, „interpretacja" faktów, zjawisk, procesów. Wczuwamy się w stany psychiczne uczniów, staramy się być na równi z nimi, z ich pozycji oceniamy sytuację szkolną, nawiązujemy dialog. Próbujemy zbadać to, co nie poddaje się liczeniu i mierzeniu - sferę przeżyć psychicznych uczniów, ich świat wartości, wewnętrznych doświadczeń, marzenia, lęki. Człowiek nie jest przecież bytem dającym się zredukować do wskaźników. Jest istotą holistyczną, integralną, która tylko częściowo jest poznawalna. Ta orientacja humanistyczna zdobywa coraz większe uznanie, a badania jakościowe (hermeneutyczno-fenomenologiczne) zaczynają dominować w pracach awansowych. Coraz częściej, chcąc poznać możliwie wielostronnie badane zjawisko, prowadzimy badania triangulacyjne.

Jerzy Niemiec, dokonując analizy intencji przemian w dydaktyce, już przed laty celnie wskazywał, że

ważną intencją jest wołanie o humanizację dydaktyki jako tej cechy pedagogiki, która dotąd jest najczęściej sytuowana w obszarze wyliczalnych kryteriów nauk matematyczno-przyrodniczych. Jest to intencja, by uwzględnić w procesie kształcenia całego człowieka, a więc i w tym, co nie jest policzalne, co mieści się w jakościowych ocenach naszych poczynańn ${ }^{4}$.

3 B. Śliwerski, Pedagogika jako nauka, [w:] Z. Kwieciński, B. Śliwerski (red.), Pedagogika. Podręcznik akademicki, PWN, Warszawa 2019, s. 18.

4 J. Niemiec, Intencje przemian w dydaktyce, [w:] K. Denek, F. Bereźnicki, J. Świrko-Pilipczuk (red.), Przemiany dydaktyki na progu XXI wieku, Agencja Wydawnicza Kwadra, Szczecin 2000, s. 42. 
Choćby z tej metodologicznej perspektywy, przydzielenie pedagogiki, a tym samym dydaktyki, do jednej dziedziny jest nieco sztuczne. Powinna mieć ona status dyscypliny międzydziedzinowej. Jak uzasadnia Bogusław Śliwerski „Pedagogika nie jest ani tylko humanistyczna, ani tylko społeczna, gdyż przedmiot jej badań mieści się w obu dziedzinach"5. Jest zatem nauką humanistyczno-społeczną, którą cechuje myślenie według wartości. Jednakże biorąc pod uwagę wielowiekowe tradycje uprawiania pedagogiki na świecie, fundamentem dla teorii i praktyki, powinna być wiedza humanistyczna, a nie z nauk społecznych. Nie oznacza to, że nauki społeczne powinny być pedagogom obojętne czy przez nich pomijane. Wprost odwrotnie, ale tylko i wyłącznie na zasadzie dopełnienia i pogłębienia wiedzy o przedmiocie badań pedagogicznych.

Dydaktyka jako subdyscyplina pedagogiki jest nauką głęboko zakorzenioną w naukach humanistycznych, chociaż jej związki z praktyką społecznej edukacji i wychowania pozwalają dostrzec także ścisłe koneksje z naukami społecznymi, jak socjologia, psychologia, nauki o polityce.

Myśląc o dydaktyce jako nauce, dostrzegając potrzebę jej odbudowy i modernizacji, warto pamiętać, że ma ona trwałe podstawy w postaci wartościowych prac, poglądów, wskazań dydaktycznych, czasami skazywane niesłusznie na zapomnienie, jak pisze Józef Półturzycki ${ }^{6}$. Mowa tu o znanych twórcach kształcenia, w osobach Kazimierza Twardowskiego, Bogdana Nawroczyńskiego, Kazimierza Sośnickiego, Jana Władysława Dawida, Sergiusza Hessena, Zygmunta Mysłakowskiego, Wincentego Okonia, Tadeusza Nowackiego, Kazimierza Denka, Władysława Zaczyńskiego, Czesława Kupisiewicza, Krzysztofa Kruszewskiego, Tadeusza Lewowickiego, Józefa Półturzyckiego, Bolesława Niemierko i wielu innych uznanych profesorów dydaktyki ogólnej. Ich prace mają trwałą wartość naukową: aksjologiczną, filozoficzną, kulturową, epistemologiczną, psychologiczną. Należy ubolewać, że na przykład teoria wielostronnego kształcenia Wincentego Okonia, tak przemyślnie skonstruowana, traci na znaczeniu, ginie w gąszczu wielości

$5 \quad$ B. Śliwerski, Pedagogika jako nauka..., s. 20.

6 J. Półturzycki, Niepokój o dydaktykę, Wydawnictwo Naukowe Instytutu Technologii Eksploatacji - Państwowy Instytut Badawczy, Warszawa - Radom 2014, s. 9. 
paradygmatów dydaktycznych, a nawet jest pomijana w opracowaniach edukacyjnych oraz poszukiwaniach modernizacji oświaty.

Z drugiej strony, nie sposób odmówić racji Tadeuszowi Lewowickiemu, który już wiele lat temu pisał, że „dydaktyka przeżywa okres swoistego zmęczenia utrwalonym paradygmatem"7. Zgłaszał potrzebę odejścia od takiego paradygmatycznego (w znaczeniu kuhnowskim a więc jednego) ujęcia. Stanowisko to wzmacnia Teresa Hejnicka-Bezwińska, twierdząc, że „Żadna teoria, żaden paradygmat nie ma monopolu na prawdę"8. To oznacza, że nie istnieje jeden, uznany przez wszystkich sposób uprawiania dydaktyki jako dyscypliny naukowej, ujmowania jej przedmiotu badań i stosowanych rozwiązań metodologicznych. Dobrze więc, że pojawiają się próby rysowania różnych modeli rozumienia i uprawiania dydaktyki - teorii, ale i praktyki dydaktycznej, żeby przywołać modele uczenia się i nauczania B. Joyce'a, E. Calhouna i D. Hopkinsa', ujęcia dydaktyki według uczonych niemieckich, np. F.W. Krona, a nade wszystko paradygmatyczną mapę dydaktyki autorstwa Doroty Klus-Stańskiej ${ }^{10}$. Jej zasługą jest wskazanie najważniejszych współcześnie istniejących kierunków rozwoju dydaktyki, uporządkowanie jej odmian w postaci czytelnej typologii obejmującej: 1) dydaktyki obiektywistyczne (normatywna, instrukcyjna, neurodydaktyka), 2) dydaktyki konstruktywistyczno-interpretatywne (humanistyczna, konstruktywistyczna, konektywistyczna), 3) dydaktyki transformatywne (krytyczna, libertariańska) oraz budowanie świadomości współistnienia w dydaktyce różnorodnych perspektyw teoretycznych, metodologicznych i problemowych ${ }^{11}$.

$7 \quad$ T. Lewowicki, Tradycje i współczesne przemiany dydaktyki, „Rocznik Pedagogiczny” 1995, nr 18, s. 63.

8 T. Hejnicka-Bezwińska (red.), Racjonalność pedagogiki, Wydawnictwo Uczelniane WSP, Bydgoszcz 1995, s. 20.

9 Zob. B. Joyce, E. Calhoun, D. Hopkins, Przykłady modeli uczenia się i nauczania, tłum. K. Kruszewski, WSiP, Warszawa 1999.

10 Zob. m.in. D. Klus-Stańska, Paradygmaty dydaktyki. Myśleć teoria o praktyce, Wydawnictwo Naukowe PWN, Warszawa 2019; Eadem, Polska rzeczywistość dydaktyczna - paradygmatyczny taniec św. Wita, [w:] L. Hurlo, D. Klus-Stańska, M. Łojko (red.), Paradygmaty współczesnej dydaktyki, Oficyna Wydawnicza „Impuls”, Kraków 2009, s. 66 i n.

11 Por. D. Klus-Stańska, Teorie kształcenia, [w:] Z. Kwieciński, B. Śliwerski (red.), Pedagogika. Podręcznik akademicki, PWN, Warszawa 2019, s. 245-266. 
Przejawem owej różnorodności może być kreowanie rozmaitych teoretycznych koncepcji współczesnej dydaktyki, o nierzadko zaskakujących nazwach, np. dydaktyka paliatywna ${ }^{12}$. Jej twórca - Axel Krommer - wykorzystał metaforę paliatywnej opieki do wyjaśnienia zachodzącej na świecie rewolucji technologicznej przekładającej się na zmiany w wiedzy, w uczeniu się, a tym samym w szkole jako instytucji. Uznał, że klasyczna szkoła z systemem klasowo-lekcyjnym, nauczaniem frontalnym, prowadząca edukację w paradygmacie dydaktyki opartej na wynalazku Gutenberga, weszła w stan terminalnej choroby i musi umrzeć. Jak napisał na swoim blogu Bogusław Śliwerski: „Tak kończy się szkoła analogowego paradygmatu. Nadchodzi edukacja Turinga (od nazwiska jednego z twórców informatyki)"13.

Na trudny czas przetrwania potrzebna jest dydaktyka paliatywna, która ma pomóc nauczycielom, uczniom i rodzicom w rozstaniu się z tradycyjną edukacją na rzecz uczenia się konektywistycznego, konstruktywistycznego, uczenia się z pomocą nauczycieli jako lekarzy ludzkich dusz, będących tutorami, przewodnikami, facylitatorami. Celem dydaktyki paliatywnej nie jest wyleczenie chorej szkoły, patologicznej, nieskutecznej edukacji, ani też zatrzymanie procesu chorobowego, ale przede wszystkim poprawienie jakości życia nauczycieli i uczniów w tym stadium choroby, by przejść do nowego życia w ponowoczesnym zdygitalizowanym świecie.

Dokonujące się rozległe i głębokie przemiany społeczne, kulturowe, polityczne, ekonomiczne, filozoficzne, edukacyjne ${ }^{14}$ implikują zmiany w systemie kształcenia, które powinny znaleźć umocowanie w teorii kształcenia, determinując nowy kształt dydaktyki ogólnej, czy też wyznaczając pewne kierunki przemian w tej dyscyplinie naukowej. Są one następstwem przemian w filozofii edukacyjnej, w której poddano krytyce edukację adaptacyjną, eksponując walory krytyczno-kreatywne

12 A. Krommer, Paradigmen und palliative Didaktik, Oder: Wie Medien Wissen und Lernen prägen, 2019; cyt. za: B. Śliwerski: https://sliwerski-pedagog.blogspot.com/ 2020/04/dydaktyka-paliatywna-to-nie.html (dostęp: 07.05.2020).

$13 \mathrm{https}$ //sliwerski-pedagog.blogspot.com/2020/04/dydaktyka-paliatywna-to-nie. html (dostęp: 07.05.2020).

14 Przykładowe wyznaczniki przemian w różnych sferach: rozwój społeczeństwa uczącego się, postępująca globalizacja, wzrost znaczenia wiedzy, rozwój technologii informacyjnych, przemiany w gospodarce, problemy na rynku pracy, niepokój o jakość kształcenia w kontekście masowości kształcenia. 
edukacji emancypacyjnej. Są także następstwem wyraźnego umacniania się orientacji humanistycznej w dydaktyce. Źródła przemian w uprawianiu dydaktyki/myśleniu o dydaktyce trzeba też upatrywać w pojawianiu się nowych koncepcji teoretycznych dotyczących mechanizmów leżących u podstaw myślenia, rozumowania i uczenia się człowieka, teorii uczenia się zrywających z szeroko akceptowaną teorią behawioryzmu, na rzecz koncepcji psychologii humanistycznej, psychologii poznawczej w tym konstruktywizmu poznawczego i społeczno-kulturowego. Awizowane zmiany w systemie kształcenia dotyczą tak naprawdę wszystkich elementów systemu: przedmiotowych - w postaci celów, treści, procesu, stosowanych metod, środków i form, oceny, kontroli, ewaluacji; oraz podmiotowych - w postaci miejsca i roli nauczyciela i uczących się, a także relacji interpersonalnych między nimi ${ }^{15}$.

Dostrzegając pilną potrzebę odbudowy i rekonstrukcji dydaktyki polskiej, warto pamiętać o tradycji naukowej (w sferze teorii) i oświatowej (w sferze praktyki). Warto też otworzyć się na doświadczenia i innowacje $z$ innych krajów zarówno w obszarze metod kształcenia, jak i organizacji. Owa otwartość musi też dotyczyć inter-, a nawet transdyscyplinarności, choć z poszanowaniem tożsamości i autonomiczności przedmiotu dydaktycznego poznania. Bowiem za radą Lecha Witkowskiego „konieczne jest otwarcie się oraz doszukiwanie się nowych inspiracji, a nie okopanie się, zamknięcie w starych nawykach narracyjnych"16.

Dydaktykę należy spostrzegać i uprawiać integralnie, jako naukę funkcjonującą nie tylko horyzontalnie, ale i wertykalnie na kontinuum retrospektywności, deskryptywności, transgresji i prospektywności; wiążącej zatem integralnie to, co było, jest tu i teraz, staje się i będzie ${ }^{17}$.

\footnotetext{
15 A. Krajewska, Współdziałanie dydaktyczne nauczycieli akademickich i studentów a jakość kształcenia na przykładzie studiów pedagogicznych, Wydawnictwo Trans Humana, Białystok 2016, s. 31.

16 L. Witkowski, Uwagi o interdyscyplinarności w pedagogice (z perspektywy epistemologii krytycznej), „Rocznik Pedagogiczny” 2010, t. 33, s. 63.

17 W. Andrukowicz, Dydaktyka wartości, faktów i sposobów działania, Instytut Studiów nad Rodziną ATK, Szczecin 1995; L. Witkowski, Uwagi o interdyscyplinarności w pedagogice. (Z perspektywy epistemologii krytycznej), „Rocznik Pedagogiczny” 2010, t. 33, s. 63; A. Krajewska, Współdziałanie dydaktyczne nauczycieli akademickich i studentów..., s. 31.
} 
W opisywanym nurcie myślenia o dydaktyce jako nauce, nie można pominąć, a wręcz trzeba wyeksponować spełnianie przez nią kryteriów naukowości, począwszy od jasno zdefiniowanego przedmiotu badań (choć ten jest różnie określany przez autorów podręczników), przez posiadanie własnej aparatury terminologicznej i metodologicznej, operowanie systemem twierdzeń, po własną historię. Specjalizacja dokonująca się we wszystkich dziedzinach życia, nie omija też dydaktyki. Stąd trudno jest mówić o jakiejś jednej, monistycznie pojmowanej dydaktyce ogólnej. Zaczynamy mieć do czynienia ze stopniowo tworzącą się strukturą nauk dydaktycznych, na którą składają się dydaktyki szczegółowe, do niedawna zwane metodykami nauczania poszczególnych przedmiotów, oraz subdyscypliny dydaktyki ogólnej, tzw. poddydaktyki, np. dydaktyka szkoły wyższej, dydaktyka wojskowa, medyczna, ontodydaktyka, neurodydaktyka.

Dydaktyka jest zatem bez wątpienia nauką - jedną z podstawowych subdyscyplin pedagogiki - nauką żywą, o znakomitym dorobku, bogatej historii, wielu odmianach i dużych możliwościach rozwoju oraz znacznym potencjale twórczego oddziaływania na praktykę edukacyjną.

\section{Dydaktyka jako sztuka}

Dydaktyka będąc nauką, pozostaje także sztuką, oczywiście w greckim, szerokim rozumieniu (techne). Trudno nie zgodzić się z wykładnią znakomitego filozofa, profesora Uniwersytetu Jagiellońskiego Władysława Stróżewskiego, który twierdzi, że pedagogika (czytaj: dydaktyka) jest „sztuką ze wszystkich najdoskonalszą. Jej przedmiotem jest przecież żywy człowiek, a celem tworzenie czy kształtowanie, jeśli nie wręcz powoływanie do bytu jego człowieczeństwa"18.

Konstytutywnym pojęciem dydaktyki rozumianej jako teoria procesu kształcenia (nauczania-uczenia się oraz wychowania intelektualnego) i samokształcenia, obok dominującego współcześnie „uczenia się”, pozostaje „nauczanie”, które rzecz jasna wspiera się na ukierunkowujących je podstawach naukowych. Jak w przypadku większości przedsięwzięć człowieczych, niektóre aspekty nauczania nie poddają się prostej kodyfikacji. Sama zaś wiedza naukowa nie wystarcza jako

18 W. Stróżewski, Logos, wartość, miłość, Wydawnictwo Znak, Kraków 2013, s. 43. 
oparcie dla nich. Nathaniel Gagne z Uniwersytetu Stanforda, czołowy amerykański pedagog, charakteryzował sztukę nauczania jako

sztukę instrumentalną albo praktyczną, nie jako sztukę piękną, która tworzy piękno dla niego samego. Jako sztuka instrumentalna, nauczanie - we współczesnej dydaktyce, która przestaje być nauką normatywną (dop. mój - A.K.) - zrywa z receptami, formułami i algorytmami. Wymaga improwizacji, spontaniczności. Wymaga wyczucia formy, stylu, tempa, rytmu, stosowności i korzystania z tego wyczucia w sposób tak skomplikowany, że nawet komputery nie sprostałyby temu, tak samo jak nie potrafią dojść do tego, co udaje się matce ze swoim pięcioletnim dzieckiem, i tak samo, jak nie dorównają zakochanym w prowadzeniu flirtu ${ }^{19}$.

Za takim właśnie rozumieniem dydaktyki - jako nauki, ale i sztuki - przede wszystkim sztuki dialogu między nauczającymi i uczącymi się, a szczególnie sztuki wskazania, zrozumienia, przekonania i zaakceptowania przez obie strony ograniczeń i możliwości komunikacyjnych $^{20}$ - używając retoryki W. Andrukowicza - optuję.

\section{Dydaktyka jako przedmiot akademicki}

Dydaktyka jest także przedmiotem akademickim, występującym pod różnymi nazwami i w różnym wymiarze godzin w planach studiów pedagogicznych. Dedykowana jako przedmiot podstawowy w kształceniu nauczycieli i pedagogów, wskazuje jak uczyć i wychowywać, jak wdrażać do samodzielności, samokształcenia i uczestnictwa w kulturze. Niestety dydaktyka jako prymarny przedmiot w kanonie studiów pedagogicznych jest marginalizowana. Kazimierz Denek zabiegał o przywrócenie jej należnego miejsca na studiach pedagogicznych i nadanie jej właściwego sensu. „Leży ono - pisał - w interesie wszystkich nauczycieli, pracowników naukowo-dydaktycznych i studentów studiów pedagogicznych" ${ }^{21}$. Tym bardziej, że wymagania wobec nauczycieli XXI wieku są bardzo wysokie. Oczekuje się od nich coraz

19 D.H. Schunk, Learning theories: An educational perspective, Paperback - International Edition, Columbus 2008, s. 286.

20 W. Andrukowicz, Status dydaktyki uniwersyteckiej, „Toruńskie Studia Dydaktyczne” 1989, nr 13/14, s. 50.

21 K. Denek, Dyskusja wokół dydaktyki, „Nowa Szkoła” 2014, nr 2, s. 14. 
lepszego przygotowania merytorycznego i metodycznego, władania obszernym zasobem wiedzy przedmiotowej, pedagogicznej, społecznej i z zakresu kultury. Jest to zawód zaufania społecznego, o którym Zygmunt Freud mówił, że należy do zawodów niemożliwych, czyli takich, że uprawianie tego zawodu powoduje niedosyt i u osoby, która go wykonuje, i otoczenia społecznego. W publikacjach z pogranicza filozofii i pedagogiki czytamy, że zawód nauczyciela - to misja, powołanie. Ale żeby skutecznie wypełniać misję, czy realizować powołanie trzeba być fachowcem, czyli dopiero na profesji - twierdzi Stefan Kwiatkowski - można budować misję. Dziś już nie wystarcza, że nauczyciel lubi dzieci i jest dla nich serdeczny. Nie wystarcza też, by w swojej pracy opierał się wyłącznie na intuicji, własnych upodobaniach czy potocznej mądrości. Dzisiejszy nauczyciel ma obowiązek, stosując najlepsze metody, pomagać uczniom opanować podstawowe umiejętności i wykształcić postawy; ma obowiązek posługiwać się sposobami, których skuteczność została dowiedziona i podobnie jak przedstawicieli innych profesji - lekarzy, prawników, architektów - obowiązuje go utrzymywanie uznanych standardów zawodowych.

Dydaktycy ogólni są współodpowiedzialni za wykształcenie nie tyle specjalistów i zawodowców (to domena dydaktyków szczegółowych), co refleksyjnych, twórczych profesjonalistów, nauczycieli skutecznych, którzy:

1) rozumieją naukowe podstawy procesu kształcenia (władają zasobem wiedzy psychologicznej, filozoficznej, socjologicznej, dydaktycznej);

2) umieją posłużyć się repertuarem najlepszych strategii kształcenia uruchamiając różne rodzaje uczenia się, wykorzystując różne style uczenia się, systemy reprezentacyjne uczniów oraz możliwości mózgu w procesie kształcenia;

3) są chętni i zdolni do refleksji i rozwiązywania problemów;

4) traktują uczenie się nauczania jako proces trwający przez całe życie.

Te przykładowe cechy efektywnego nauczyciela - to swoiste idee przewodnie w dydaktycznym myśleniu i działaniu.

Kazimierz Wenta wskazywał, że między dydaktykami ogólnymi, zwłaszcza mającymi ograniczone doświadczenie nauczycielskie a metodykami nauczania przedmiotowego ujawnia się ograniczone zaufanie kompetencyjne. Wynika to z dynamiki zmian w edukacji, które 
miewają akcenty ze sfery polityki i nie zawsze są źródłem pogłębionych badań naukowych. Z kolei metodycy nauczania przedmiotowego na ogół deklarują, że aktywnie uczestniczą w tych edukacyjnych zmianach, obarczają natomiast dydaktyków ogólnych nastawieniem na dawne teorie nauczania, ponieważ nie nadążają oni - w opinii metodyków - za zmianami w uczelni i szkole oraz praktyce nauczycielskiej $^{22}$.

\section{Egzemplifikacja dydaktycznego myślenia i działania}

Wychodząc naprzeciw jakże cennej sugestii Stanisława Palki, iż tradycyjne uprawianie dydaktyki ogólnej - autor określa je „gabinetowym", nie daje szansy przebicia się do praktyków-nauczycieli, ale i ugruntowania pozycji wśród innych nauk pedagogicznych, projekty badawcze podejmowane przez dydaktyków ogólnych winny wpisywać się w podział i układ problemów zaproponowany przez autora, obejmujący: 1) problemy ściśle praktyczne, 2) dydaktyczne problemy teoretyczne służące odkrywaniu prawidłowości pedagogicznych mogących być podstawą budowania systemu teoretycznej wiedzy pedagogicznej, 3) dydaktyczne problemy teoretyczno-praktyczne, wiążąc dwie orientacje w uprawianiu dydaktyki, 4) problemy metateoretyczne i metametodologiczne, gdyż ten rodzaj problemów ma szczególną doniosłość poznawczą we współczesnej dydaktyce ${ }^{23}$.

Uogólniając, dydaktycy ogólni prowadzą badania: 1) specyficznie dydaktyczne - czyli badania składników procesu kształcenia, 2) z pogranicza dydaktyki i innych nauk pedagogicznych, np.: teorii wychowania, pedagogiki społecznej, andragogiki, pedagogiki/edukacji międzykulturowej, pedagogiki porównawczej i polityki oświatowej, pedagogiki resocjalizacyjnej, pedagogiki medialnej, 3) z pogranicza dydaktyki i nauk pomocniczych, np. socjologii, medycyny, 4) są otwarci na inicjatywy praktyków i impulsy płynące z praktyki ${ }^{24}$.

22 K. Wenta, Fraktalność zaufania wśród dydaktyków ogólnych i metodyków edukacji przedmiotowej, „Labor et Educatia” 2014, nr 2.

23 S. Palka, Pedagogika w stanie tworzenia. Kontynuacje, Wydawnictwo Uniwersytetu Jagiellońskiego, Kraków 2003, s. 97.

24 Por. Idem, Badania z pogranicza pedagogiki i nauk pomocniczych, [w:] S. Palka (red.), Pogranicza pedagogiki i nauk pomocniczych, Wydawnictwo Uniwersytetu Jagiellońskiego, Kraków 2004, s. 313-315. 
Stanisław Palka, wytyczając kierunki rozwoju dydaktyki ogólnej, wskazał na potrzebę skoncentrowania działań poznawczo-badawczych na:

1) metateorii dydaktycznej;

2) dydaktyce teoretycznie zorientowanej;

3) dydaktyce praktycznie zorientowanej ${ }^{25}$.

Nasze myślenie i działanie dydaktyczne ${ }^{26} \mathrm{w}$ pewnym sensie zawiera się w każdym nurcie, bowiem:

1) przeniknięte jest troską o status współczesnej dydaktyki, jej miejsce w systemie nauk charakteryzuje się namysłem nad stanem i rozwojem dydaktyki jako nauki, kierunkami jej przemian i rolą dydaktyki ogólnej na tle innych subdyscyplin pedagogicznych, związkiem dydaktyki ogólnej z dydaktykami szczegółowymi i potrzebą ciągłego kształtowania nowych kompetencji nauczycieli w dobie zmieniającej się dynamicznie edukacji. Ponadto uwzględniamy współczesne uwarunkowania istotne w rozwoju dydaktyki jako nauki, które powodują konieczność m.in. nowego definiowania jej poszczególnych elementów. W dydaktycznym myśleniu i działaniu kierujemy się troską o status dydaktyki szkoły wyższej, jej rozwój i znaczenie w edukacji akademickiej, jak również wspieranie doskonalenia kompetencji dydaktycznych nauczycieli akademickich;

2) intencją naszego myślenia i działania dydaktycznego jest budowanie wiedzy teoretycznej służącej wyjaśnianiu, rozumieniu i interpretowaniu faktów, zjawisk i procesów. Służą temu organizowane cyklicznie od 2001 roku Augustowskie Spotkania Naukowe „Edukacja w dialogu i perspektywie” o wyraźnie akcentowanym profilu dydaktycznym, jak również wieloautorskie monografie (24 tomy), będące ich pokłosiem;

3) nasze dydaktyczne myślenie i działanie służy praktyce. Wynikające z badań wnioski i postulaty mają na celu ulepszanie praktyki edukacyjnej, podobnie jak wypromowane rzesze magistrów pedagogiki, przygotowanych do prowadzenia badań

$\overline{25}$ Idem, Pedagogika w stanie tworzenia..., s. 106.

26 Używając określenia „nasze myślenie i działanie dydaktyczne”, odwołuję się do doświadczeń naukowo-badawczych białostockich akademików funkcjonujących w strukturach uniwersyteckich jako dydaktycy ogólni. 
w działaniu. Ponadto wyniki badań znacząco wzbogacają problematykę realizowanych zajęć dydaktycznych (wykładów, ćwiczeń i fakultetów), służą też doskonaleniu warsztatu naukowego i dydaktycznego nauczycieli akademickich, ich samokształceniu oraz rozwojowi zawodowemu.

Znakomitą rekapitulację rozważań podjętych w artykule może stanowić przesłanie Doroty Klus-Stańskiej zawarte w następującym sformułowaniu: „Rozumieć dydaktykę to rozumieć jej złożoność, różnorodność i bogactwo, ale też respektować konieczność uwrażliwienia się na napięcia i polemiki oraz nieredukowalne różnice między niektórymi odmianami teorii i praktyki dydaktycznej"27.

\begin{abstract}
The aim of the article is to present three currents of thinking about didactics: 1) as a science, 2) as art and 3) as an academic subject. The position of didactics as one of the basic subdisciplines of pedagogy in systematic science was presented. The question whether didactics belong to social sciences was raised. The need to rebuild and reconstruct didactics was emphasized, remembering about its permanent foundations, complexity, and diversity. Directions of development and varieties of didactics were recalled. Attention was paid to the problem of marginalizing general didactics as an academic subject in the curricula of pedagogical studies. The narrative was given a tripartite structure complemented with examples of didactic thinking and action, which is part of the systematics of problems proposed by Stanisław Palka.
\end{abstract}

\title{
Bibliografia
}

Andrukowicz W., Dydaktyka wartości, faktów i sposobów działania, Instytut Studiów nad Rodziną ATK, Szczecin 1995.

Andrukowicz W., Status dydaktyki uniwersyteckiej, „Toruńskie Studia Dydaktyczne" 1989, nr 13/14.

Denek K., Dyskusja wokół dydaktyki, „Nowa Szkoła” 2014, nr 2.

Hejnicka-Bezwińska T. (red.), Racjonalność pedagogiki, Wydawnictwo Uczelniane WSP, Bydgoszcz 1995.

Joyce B., Calhoun E., Hopkins D., Przykłady modeli uczenia się i nauczania, tłum. K. Kruszewski, WSiP, Warszawa 1999.

Klus-Stańska D., Paradygmaty dydaktyki. Myśleć teorią o praktyce, Wydawnictwo Naukowe PWN, Warszawa 2019.

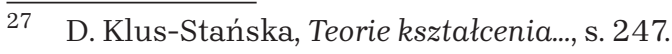


Klus-Stańska D., Polska rzeczywistość dydaktyczna - paradygmatyczny taniec św. Wita, [w:] L. Hurlo, D. Klus-Stańska, M. Łojko (red.), Paradygmaty współczesnej dydaktyki, Oficyna Wydawnicza „Impuls”, Kraków 2009.

Klus-Stańska D., Teorie kształcenia, [w:] Z. Kwieciński, B. Śliwerski (red.), Pedagogika. Podręcznik akademicki, PWN, Warszawa 2019.

Krajewska A., Współdziałanie dydaktyczne nauczycieli akademickich i studentów a jakość kształcenia na przykładzie studiów pedagogicznych, Wydawnictwo Trans Humana, Białystok 2016.

Lewowicki T., Tradycje i współczesne przemiany dydaktyki, „Rocznik Pedagogiczny" 1995, nr 18.

Niemiec J., Intencje przemian w dydaktyce, [w:] K. Denek, F. Bereźnicki, J. Świrko-Pilipczuk (red.), Przemiany dydaktyki na progu XXI wieku, Agencja Wydawnicza Kwadra, Szczecin 2000.

Palka S., Badania z pogranicza pedagogiki i nauk pomocniczych, [w:] S. Palka (red.), Pogranicza pedagogiki i nauk pomocniczych, Wydawnictwo Uniwersytetu Jagiellońskiego, Kraków 2004.

Palka S., Pedagogika w stanie tworzenia. Kontynuacje, Wydawnictwo Uniwersytetu Jagiellońskiego, Kraków 2003.

Półturzycki J., Niepokój o dydaktykę, Wydawnictwo Naukowe Instytutu Technologii Eksploatacji - Państwowy Instytut Badawczy, Warszawa - Radom 2014.

Schunk D.H., Learning theories: An educational perspective, Paperback International Edition, Columbus 2008.

Stróżewski W., Logos, wartość, miłość, Wydawnictwo Znak, Kraków 2013.

Śliwerski B., Pedagogika jako nauka, [w:] Z. Kwieciński, B. Śliwerski (red.), Pedagogika. Podręcznik akademicki, PWN, Warszawa 2019.

Wenta K., Fraktalność zaufania wśród dydaktyków ogólnych i metodyków edukacji przedmiotowej, „Labor et Educatia” 2014, nr 2.

Witkowski L., Uwagi o interdyscyplinarności w pedagogice (z perspektywy epistemologii krytycznej), „Rocznik Pedagogiczny” 2010, t. 33.

\section{Netografia}

Krommer A., Paradigmen und palliative Didaktik, Oder: Wie Medien Wissen und Lernen prägen, 2019, https://axelkrommer. com/2019/04/12/paradigmen-und-palliative-didaktik-oder-wiemedien-wissen-und-lernen-praegen/

Śliwerski B., Dydaktyka paliatywna to nie tanatopedagogika, https://sliwerski-pedagog.blogspot.com/2020/04/dydaktyka-paliatywna-tonie.html. 